\title{
Al-Madãris
}

VOL. 2, NO. 1,2021

E-ISSN: 2745-9950

https://journal.staijamitar.ac.id/index.php/almadaris

\section{KUALITAS HADIS "MANJARRA TSAUBAHU” STUDI KRITIK SANAD DAN MATAN HADIS}

\author{
Muhammad Nasir \\ Prodi Hukum Ekonomi Syariah (Muamalah) STAI Jamiatut Tarbiyah Lhoksukon \\ Munasmubin78@gmail.com
}

\begin{abstract}
This study examines the quality of the traditions "manjara tsaubahu", that they explain the prohibition of lengthening cloths or pants with arrogant intentions, whether it is being arrogant to Allah or to others, being arrogant to Allah is where when you are worshiping Allah. Then the hadiths use several kinds of commands in terms of prohibitions, including; By threatening to be reluctant by Allah, there are also those who do not accept their worship (do not get rewarded) and so on. So that if we lengthen the cloth or pants with the intention of being arrogant, it is prohibited by Allah. The main focus in this research is the sanad and observations of the Prophet's hadiths which contain the "manjaara tsaubahu". This research is library research with the main reference being the books of the hadiths of al-Kutub al-Tis'ah (The Nine Main Books). Hadith), and maktabah syamilah. Besides the hadith books mentioned above, books related to takhrij al-hadith are also references in this study, such as: Ushul al-Takhrij wa Dirasat al-Asanid. Research methodology of the Prophet's hadith written by Syuhudi Ismail, and others. To examine the narrators of Hadith, the books that are used as references are related to the observational study of hadith. The result of this research is the authentic quality hadith sanad, namely the history of Abu Dawud. From the eyes of the hadith, the quality of authenticity does not contradict the Qur'an and authentic traditions, common sense, historical facts, language and with Islamic principles.
\end{abstract}

Keywords: Hadith criticism, Matan, Sanad, Takhrij.

$\overline{\text { Al-Madãris, Volume 2 (1), } 2021}$ 


\section{A. Pendahuluan}

Ilmu takhrij Hadis adalah ilmu yang sangat urgen dalam kajian hukum Islam, karena Hadits yang merupakan sumber hukum Islam kedua haruslah diragukan kualitasnya sebelum dapat dibuktikan bahwa dasar hukum yang dipakai tersebut adalah Hadits yang layak untuk dijadikan hujjah, yang diyakini oleh banyak ulama adalah mengetahui Hadis dan ilmu Hadits, tentu saja mengetahui ilmu Hadis ini juga mencakup ilmu takhrij Hadits. Seorang inggin meneliti sebuah Hadis dalam beramal tentu agar terhindar dari kesalahan dan tidak salah dalam mengambil sebuah Hadis yang dianggap sahih baik dari segi kualitas dan kuantitas, maka perlunya mentakhrijkan Hadis karena Hadis yang ia gunakan sebagai landasan hukumnya.

Takhrij yang kemudian digunakan untuk kajian sebuah Hadis lebih lanjut adalah mengemukakan letak asal Hadis pada sumbernya yang asli, yaitu kitab-kitab Hadis yang didalamnya dicantumkan Hadis tersebut lengkap dengan sanad-sanadnya, kualitas sanad dan kualitas Hadits tersebut (Syuhudi Ismail, 1992:42).

Penelitian ini adalah salah satu usaha dalam takhrij Hadis. Hadis yang akan ditakhrij tersebut akan dipaparkan dan disebutkan sumber-sumber aslinya pada kitab-kitab hadis beserta jalan periwayatannya, kualitas rawinya, dan kualitas Hadis tersebut.

Hadis yang ditakhrij yakni من جرثوبه ternyata kami dapatkan di semua kitab Hadits, maka dipaparkan beberapa contohnya dari setiap sumber dengan mengutamakan sanad dan sighah Hadis.

\section{B. Review Literatur}

Dalam aturan Agama Islam Allah menyuruh kita untuk menutup aurat, sebagaimana Rasulullah saw di perintahkan kepada kita sesuai dengan ketentuan yang telah di tetapkan. Maka dalam berpakaian terutama masalah Isbal yaitu menjulurkan pakaian ini ada dua bentuk yang pertama menjulurkan pakaian hingga ketanah dan menyeret-nyeretnya.Kedua menurunkan pakaina hingga di bawah mata kaki tanpa berakar kesombongan.

Ibn Hajar mengatakan dalam kitabnya Fath al-Barry mengatakan berpakaian dengan disertai dengan kesombongan adalah dosa-dosa besar ( $\mathrm{M}$. Tasyrif, tt: 32). sebagaimana Hadis di riwayatkan oleh Ahmad bin Hanbal dari Abi Tamyimah al-Hujaimiy

$$
\text { من المخيلة وإن الله تبارك وتعالى لا يحب الماق فإن أبيت فإلى الكعبين وإياك وإسبال الإزار فإن إسبال الإزار }
$$

Artinya: Jiaka kamu berpakaian hendaklah sebatas mata kaki dan hindari olehmu akan isbal kain sarung karena sesungguhnya isbal kain sarung bahagian dari kesombongan dan Allah Swt, tidak meyukai kesombongan (Ahmad Ibn Hanbal, tt:64). 


\section{Metodelogi}

Jenis penelitian ini berupa penelitian perpustakaan (Library Research). Hal ini karena seluruh data yang akan diteliti diperoleh melalui kitab-kitab hadis, dokumen dan terbitan lain yang terkait dengan objek penelitian ini.

Untuk mengetahui lebih lanjut terkait dengan bagaimana kualitas hadis yang di manjar saubahu ini, perlu upaya penulusuran hadis-hadis dimaksud dan dikaji dengan menggunakan pendekatan metode maudhui'y. Dengan metode seperti ini, akan diketahui kualitas hadis baik dari sisi sanadnya maupun matannya. Secara umum jumlah hadis tentang manjar saubahu ini sangat banyak dan tersebar di berbagai kitab hadis, maka untuk keperluan kajian ini, penulis membatasinya menjadi beberapa tema pokok tentang manjar saubahu.

Penelitian ini secara metodologis menggunakan metode penelitian hadis yaitu penelitian dalam kritik sanad dan matan. Sanad adalah rangkaian para periwayat hadis sedangkan matan merupakan isi (materi) hadis yang diriwayatkan. Dengan demikian, untuk menetapkan kualitas sebuah hadist harus dilakukan penelitian terhadap kedua aspek tersebut, sebagaimana telah dijelaskan dalam bagian pendahuluan. Selain itu, kajian ini juga mengunakan metode takhrij al-hadits bi al-maudhuiy (berdasarkan tema hadis), yaitu metode keempat, dengan mempergunakan Aplikasi Maktabah Syamilah.

Maka dalam penelitian ini penulis memfokuskan kepada sumber hadist, yakni satu hadis dalam Kitab Sunan Abi Daud, yang bersumber dari Abdullah bin Umar (A.J. Wensick, 1962:173).

\section{Hasil Kajian}

\section{Pencarian Hadis Pada Sumber Asli.}

Ketika pencaharian hadist dilakukan melalu kata faradha di dalam Kitab al-Mu'jam al-Mufahras, kami mendapatkan sangat banyak hadis. Sebagimana diketahui, penggalan hadis yang akan penulis takhrijkan adalah من جرؤبه Dalam melakukan takhrij hadis ini penulis mengunakan Kitab al-Mu'jam al-Mufahras li al-Alfadhi al-Hadits an-Nabawiy (Wensick\&Fuad A. Baqi', 1936:221). Kata kunci yang penulis gunakan adalah Manjarra tsaubahu, yang mana kata-kata tersebut terambil darinya .Bukan hanya mengunakan kitab tersebut, penulis juga mengunakan Aplikasi Maktabah Syamilah, dari sini ditemukan hadis yang menjelaskan tentang tema tersebut sebanyak 161 dari 115 kitab, dan dalam Kitab Kutub as-Sittah penulis menemukan matan hadis dan sanad yang berbeda seperti berikut:

1. Al-Bukhari dalam kitab al-Munakib nomor hadis, 3775

2. Al-Bukhari dalam kitab al-Libas nomor hadis, 5783

3. Al-Bukhari dalam kitab al-Libas nomor hadis, 5784

4. Al-Bukhari dalam kitab al-Libas nomor hadis, 5791

5. Al-Bukhari dalam kitab al-Adab nomor hadis, 6062

6. Muslim dalam kitab al-Libas wazzinah nomor hadis, 2085

7. Muslim dalam kitab al-Libas wazzinah nomor hadis, 2085

$\overline{\text { Al-Madãris, Volume 2 (1), } 2021}$ 
8. Al-Tirmizi dalam kitab al-Libas nomor hadis, 1730

9. Al-Tirmizi dalam kitab al-Libas nomor hadis, 1731

10. An-Nasa'i dalam kitab az-zinah nomor hadis 5327

11. An-Nasa'i dalam kitab az-zinah nomor hadis 5328

12. An-Nasa'i dalam kitab az-zinah nomor hadis 5335

13. An-Nasa'i dalam kitab az-zinah nomor hadis 5336

14. Ibnu Majah dalam kitab libas nomor hadis 3569

15. Ahmad bin Hambal dalam kitab Musnad al-Mukassirin minal shahabat nomor hadis 4475

16. Ahmad bin Hambal dalam kitab Musnad al-Mukassirin minal shahabat nomor hadis 4553

17. Ahmad bin Hambal dalam kitab Musnad al-Mukassirin minal shahabat nomor hadis 4994

18. Ahmad bin Hambal dalam kitab Musnad al-Mukassirin minal shahabat nomor hadis 5018

19. Ahmad bin Hambal dalam kitab Musnad al-Mukassirin minal shahabat nomor hadis 5035

20. Ahmad bin Hambal dalam kitab Musnad al-Mukassirin minal shahabat nomor hadis 5151

21. Ahmad bin Hambal dalam kitab Musnad al-Mukassirin minal shahabat nomor hadis 5166

22. Ahmad bin Hambal dalam $k$ itab Musnad al-Mukassirin minal shahabat nomor hadis 5226

23. Ahmad bin Hambal dalam kitab Musnad al-Mukassirin minal shahabat nomor hadis 5305

24. Ahmad bin Hambal dalam kitab Musnad al-Mukassirin minal shahabat nomor hadis 5328

25. Ahmad bin Hambal dalam kitab Musnad al-Mukassirin minal shahabat nomor hadis 5354

26. Ahmad bin Hambal dalam kitab Musnad al-Mukassirin minal shahabat nomor hadis 5416

27. Ahmad bin Hambal dalam kitab Musnad al-Mukassirin minal shahabat nomor hadis 5510

28. Ahmad bin Hambal dalam kitab Musnad al-Mukassirin minal shahabat nomor hadis 6168

29. Ahmad bin Hambal dalam kitab Musnad al-Mukassirin minal shahabat nomor hadis 6304

30. Malik dalam al-Jami' kitab nomor hadis 1696

31. Malik dalam al-Jami' kitab nomor hadis 1698

Maka sebagai sampel sanad dan matan dalam hadis yang ditakhrij adalah sebagai berikut:

1. Kitab Sahih Bukhari, nomor hadis 5345 dengan sanad dan matan sebagai berikut (Imam al-Bukhari, t.t.:93):

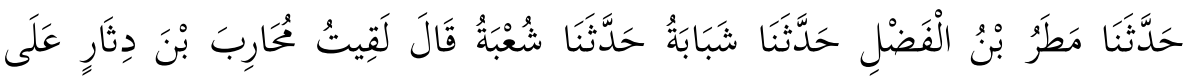

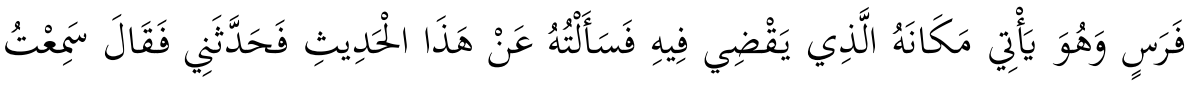

$\overline{\text { Al-Madãris, Volume 2 (1), } 2021}$ 


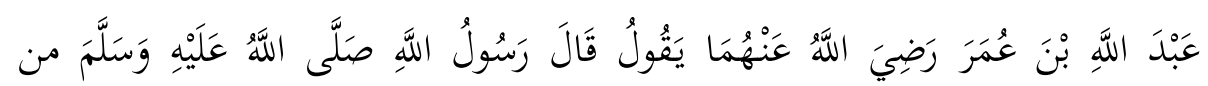

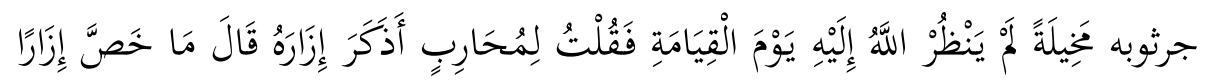

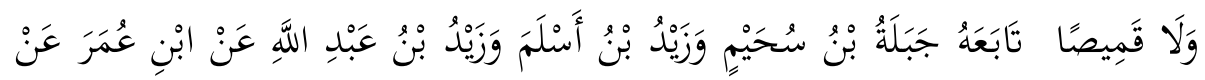

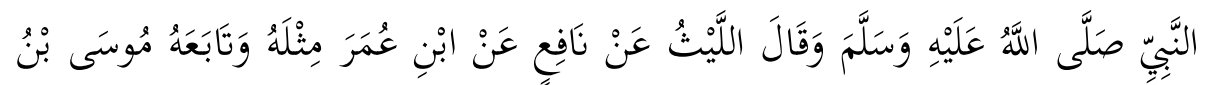

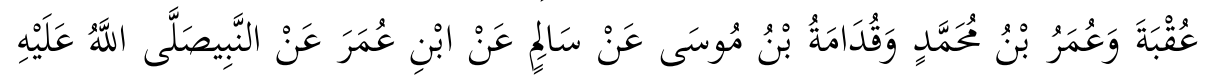

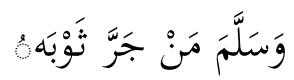

2. Kitab Shahih Muslim, nomor hadis 3889 dengan sanad dan matan sebagai berikut (Imam Muslim, 1924:452):

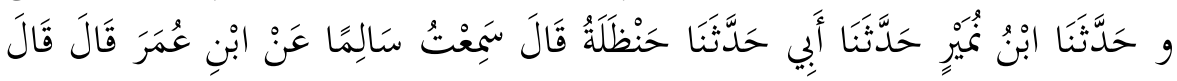

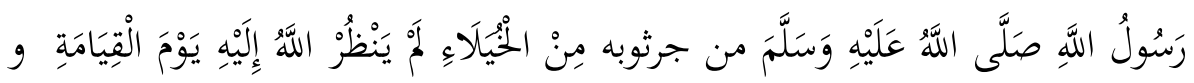

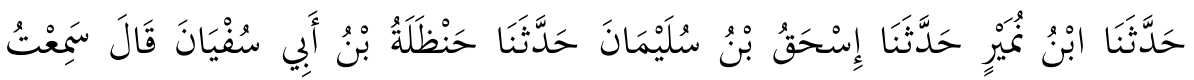

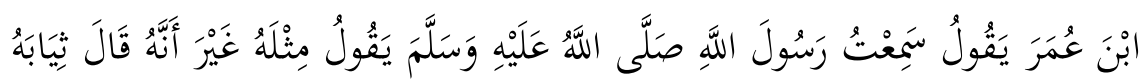

3. Kitab Sunad Ahmad bin Hanbal, nomor hadis 4662 dengan sanad dan matan sebagai berikut (Ibn Hanbal, t.t.:478):

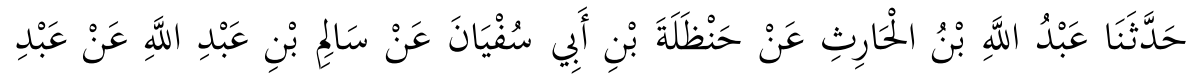

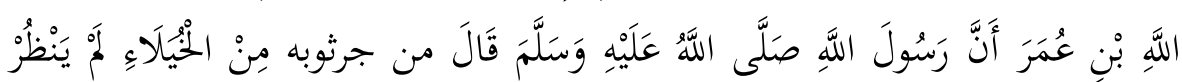

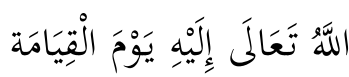

4. Kitab Sunan Tirmizi, nomor hadis 1652 dengan sanad dan matan sebagai berikut (At-Tirmidzi, t.t.:341):

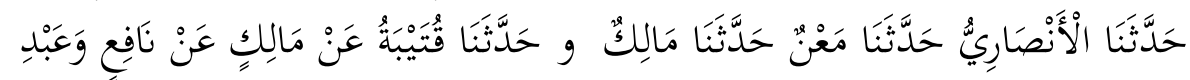

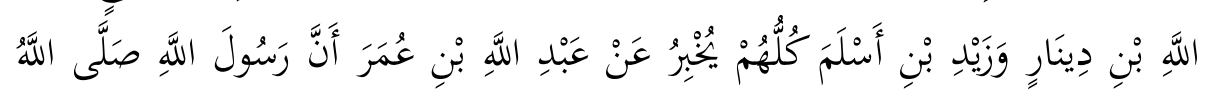

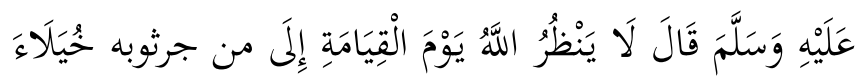

5. Kitab Sunan an-Nasa'i, nomor hadis 5233 dengan sanad dan matan sebagai berikut (An-Nasa'iy, 1978:133):

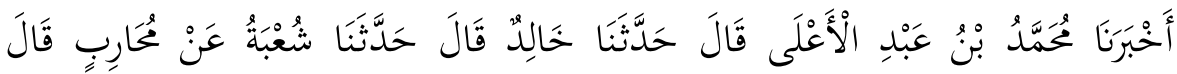

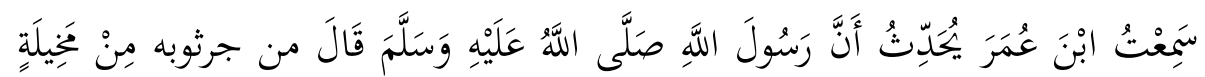

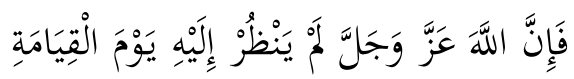


6. Kitab Sunan Ibnu majah, nomor 1026 hadis dengan sanad dan matan sebagai berikut:

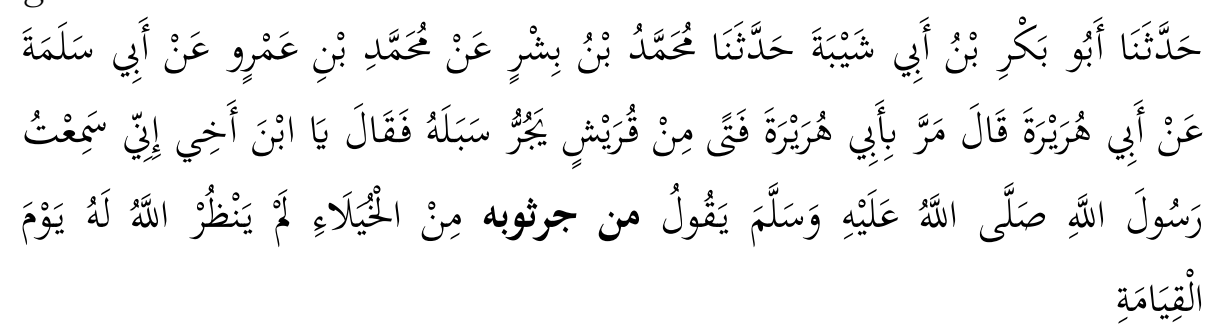

\section{E. Pembahasan}

Dalam rangka mengedentifikasi para perawi hadis diperlukan ilmu Jarh wa at-Ta'dil, di mana ilmu ini secara khusus membahas hal ihwal dan keritera para perawinya, dari segi keadilan, kejujurannya, hafalannya dan seluruh sifat-sifat yang baik maupun yang buruk, (Nuruddin, 1997:92).

Sebagai contoh hadis yang di teliti adalah yang terdapat dalam Kitab Sunan Abi Daud, dengan sanad dan matan sebagai berikut, (Imam Abu Daud as-Sijistani, 1952:122):

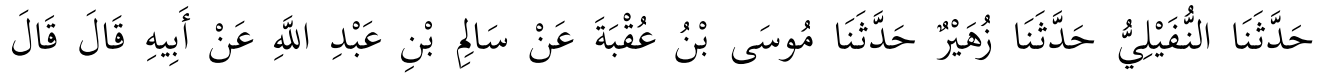

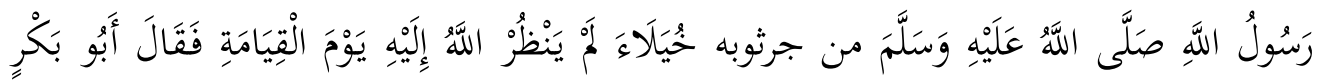

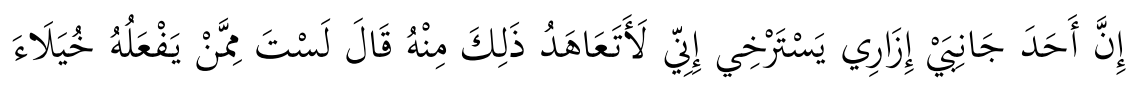

Dari berbagai riwayat di atas, inti kandungan hadis ini adalah larangan menjururkan pakaian (Isbal), "Barangsiapa menjulurkan pakaian karena kesombongan Allah Swt tidak memandang dengan pandangan kasih sanyang pada hari kiamat" Untuk lebih rinci penulis, akan menterjemahkan salah satu hadis di atas yaitu hadis yang diriwayatkan oleh Abu Daud, sebagai berikut:

"Telah menceritakan kepada kami Nufaliy, telah menceritakan kepada kami Zuhair, telah menceritakan kepada kami Musa bin 'Aqabah dari pada Salim bin 'Abdullah daripada Abinya berkata: Telah bersabda Rasulullah saw Barang siapa menjulurkan pakaian karena kesombongan niscaya Allah Swt tidak memandang degan pandangan kasih sanyang pada hari kiamat nanti. Maka berkata Abu Bakar wahai Rasulullah saw, sesungguhnya salah satu sisi belahan kainku ini turun kecuali aku menjaganya dari keadaan tersebut. Maka Rasullah saw menjelaskan engkau tidak termasuk orang yang melakukannya dengan kesombongan"

Kritik di segi sanad hadis yang riwayatkan oleh Abu Daud dari Abdullah bin Umar

a. Abu Daud.

Nama lengkapnya adalah Sulaiman ibn al-Asy'ats ibn Syadad ibn 'Amr bin 'Amir. Menurut Ibn Dassah dan al-Ajri namanya adalah Sulaiman ibn al-Asy'ats ibn Ishak ibn Basyir ibn Syadad, Abu Daud Sijistani (Al-Hafidh Ibn Hajar al-Asqallani, 1962:457). Abu Daud dilahirkan pada tahun 202 H. Dia menetap dibasrah dan meningal

$\overline{\text { Al-Madãris, Volume 2 (1), } 2021}$ 
dunia pada bulan Syawwal $275 \mathrm{H}$ (al-Asqallani: 458-459). Gurunya yang menjadi sumber hadisnya di antaranya adalah Abu Salamah alTabuzki, Abu al-Walid al-Tayalisi, Muhammad bin kaisir al-'Abdi, Muslim ibn Ibrahim, Abu 'Umaral-Hawdi, Abu Tauban al-Halabi, Abu Ja'far dan lai-lain. Dan ulama-ulama yang meriwayatkan hadis darinya adalah Abu 'Ali Muhammad ibn Ahmad ibn 'Amr al-Lu'lu'i, Abu alTaib Ahmad bin Ibrahim ibn'Abd al-Rahman al-Asyani, Abu 'Amr Ahmad ibn al-Hasan al-Basri, Abu Sa'id Ahmad ibn Muhammad ibn Ziyad al-A'rbi, dan lain-lain. berikut:

Penilaian kritikus Hadis terhadap Abu Daud adalah sebagai

1) Ahmad ibn Muhammad ibn Yasin al-Harawi berkata Abu Daud adalah salah seorang hafiz dalam bidang hadis, dan sanad-sanad hadisnya adalah berada pada tingkat derajat yang tinggi.

2) Abu Hatim mengatakan bahwa Abu Daud adalah salah satu Imam ahli dalam bidang fiqh, ilmu, hafalan, ibadah, kewara'an dan kekokohan hafalannya, tsiqat.

3) Al-Hakim mengatakan bahwa Abu Daud adalah ahli Hadis pada masanya.

4) Maslamah bin Qasem berkata Abu Daud adalah seorang yangtsiqat, zahit, memahami tentang Hadis, dan imam Hadis pada masanya (alAsqallani:459).

5) Ibn Hajar berpendapat bahwa Abu Daud adalah seorang yang tsiqat, hafiz, dan dia adalah pengarang kitab al-Sunan yaitu Sunan Abi Daud (al-Asqallani:223).

Dari pernyataan kritikus Hadis tentang Abu Daud, dapat disimpulkan bahwa Abu Daud adalah seorang yang tsiqat. Dengan demikian, maka pengakuannya bahwa dia telah menerima Hadis dari Nafili dapat dipercaya, dan sanad antara dirinya dengan Nafili adalah bersambung.

b. Nafili

Nama lengkapnya adalah 'Abdullah bin Muhammad bin 'Ali bin Nafail, kuniahnya Abu Ja'far, Beliau meriwayatkan hadis dari Abu khisamah, Malik bin Anas, Ibrahim bin Ismail dll. mendapatkan hadis dari gurunya yaitu Dhuhir bin ma'wiyah. Muridnya selain Abu Daud. Sedangkan yang meriwayatkan hadis darinya adalah Bukhari, Abu daud, at-Tirmizi, Nasa'i, dan Ibnu Majah dan lain-lain (alAsqallani:18).

Penilaian kritikus hadis tentang diri 'Abdullah bin Muhammad bin 'Ali bin Nafili, di antaranya:

1) Abu Hatim berpendapat bahwa 'Abdullah bin Muhammad bin 'Ali bin Nafail adalah tsiqat

2) Nasa'iy mengatakan 'Abdullah bin Muhammad bin 'Ali bin Nafail tsiqat

3) Darul khutni menilainya'Abdullah bin Muhammad bin 'Ali bin Nafail tsiqat

$\overline{\text { Al-Madãris, Volume 2 (1), } 2021}$ 
4) Ibnu qani' 'Abdullah bin Muhammad bin 'Ali bin Nafail menilainya tsiqat

5) Ibnu hajar asqalani 'Abdullah bin Muhammad bin 'Ali bin Nafail menilainya tsiqat (Ibn Hajar al-Asqallani:352).

Penilaian para kritikus Hadis di atas menunjukkan ahwa Abdullah bin Muhammad bin 'Ali bin Nafili adalah seorang tsiqat, sehingga karenanya pernyataan bahwa dia telah menerima riwayat Hadis dari Zuhair dapat dipercaya. Hal tersebut dapat dipercaya. Hal tersebut selanjutnya membuktikan bahwa sanad antara dia dengan zuhair adalah muttasi.

c. Zuhair bin mu'awwiyah bin hadid. Beliau meriwayatkan hadis dari Musa bin 'Aqabah, Ibrahim bin 'Aqabah, Ismail bin Abi Khalid dan lainnya. Sedangkan yang meriwayatkan hadis darinya adalah Bukhari, Muslim, Abu daud, at-Tirmizi, Nasa'i, Ibnu Majah dan lainnya.

Penilaian kritikus hadis tentang diri Zuhair bin mu'awwiyah bin hadid, di antaranya:

1) Abu Said menilai Zuhair bin mu'awwiyah bin hadid adalah tsiqat

2) Abu Hasan al-Maimuni dari Ahmad bin Hambal Suduq

3) Abu Bakar menilaianya tsiqat

4) Ahmad bin Abdullah al-Jalli tsiqah ma'mun

5) An-Nasai'i dan al-Barazi, Ibnu Hibban, Az-Zahabi mengatakan tsiqah

6) Ibn Hajar al-Asqallani menilainya tsiqah (al-Asqallani: 325).

Penilaian para kritikus Hadis di atas menunjukkan ahwa Zuhair bin mu'awwiyah bin hadid adalah seorang tsiqat, sehingga karenanya pernyataan bahwa dia telah menerima riwayat Hadis dari Musa bin Aqabah dapat dipercaya. Hal tersebut dapat dipercaya. Hal tersebut selanjutnya membuktikan bahwa sanad antara dia dengan Musa bin Aqabah adalah muttasi.

d. Musa bin 'Aqabah bin Abi 'Aiyasyi, dia adalah seorang tabi'in kuniahnya Abu Muhammad yang dilahirkan dimadinah dan wafat juga dimadinah pada $131 \mathrm{H}$. Salah satu gurunya adalah Salim bin 'Abdullah bin 'Umar bin Khatab yang di panggil dengan Abu Umar, yang dia mengambil hadis darinya, dan yang meriwayatkan Hadis darinya salah satunya adalah Zuhair bin mu'awiah bin hadij dengan kuniahnya Abu khasimah.

Penilaian para kritikus Hadis di atas menunjukkan Musan Musa bin 'Aqabah bin Abi 'Aiyasyi sebagai berikut:

1) Malik menilainya tsiqat

2) Ahmad bin Hambal Tsiqah

3) Yahya bin Mu'in Tsiqat

4) Muhammad bin Said tiqat

5) An-Nasa'i menilainya tsiqat

6) Al-'Ajalli tsiqat

7) Ibnu Hajar As-Asqalani tsiqat

$\overline{\text { Al-Madãris, Volume 2 (1), } 2021}$ 
Penilaian para kritikus Hadis di atas menunjukkan bahwa Musa bin 'Aqabah bin Abi 'Aiyasyi adalah seorang tsiqat, sehingga karenanya pernyataan bahwa dia telah menerima riwayat Hadis dari Salim bin Abdullah bin umar bin khatab dapat dipercaya. Hal tersebut dapat dipercaya. Hal tersebut selanjutnya membuktikan bahwa sanad antara dia dengan Salim bin Abdullah bin umar bin khatab adalah muttasi.

e. Salim bin Abdullah bin umar bin khatab ia adalah seorang tabi'in di lahirkan di madinah dan wafat dimadinah pada tahun $106 \mathrm{H}$, dia menerima hadis dari gurunya adalah sekaligus ayahnya adalah 'Abdullah bin Umar bin khatab bin Nafil, Ibrahim bin Abi hanifah alYamami, Ibrahim bin 'Aqabah, Bakar bin 'Atiq, 'Ibadillah bin Umar bin hafsin bin 'Ashi bin Umar, Musa bin 'Aqabah, Rafi' bin khadid, Zaid bin khatab, Sa'id bin musaib dan selainnya (al-Asqallani: 438).

Penilaian para kritikus Hadis di atas menunjukkan bahwa Salim bin Abdullah bin umar bin khatab sebagai berikut:

1) Muhammad bin Said menilaianya tsiqat

2) Al-'Ajalli tsiqat

3) Ibnu Hibban tsiqat

4) Ibnu Hajar Asqalani menilai Salim bin Abdullah bin umar bin khatab tsiqat

5) Telah berkata shalih bin Ahmad bin hambali, ishak bin rahawiyah: As-Shahu Sanid: Az-Zuhri, Salim, dari bapaknya. Berkata Ibnu Hibban tsiqat

Penilaian para kritikus Hadis di atas menunjukkan bahwa Salim bin Abdullah bin umar bin khatab adalah seorang tsiqat, sehingga karenanya pernyataan bahwa dia telah menerima riwayat Hadis dari Salim bin Abdullah bin umar bin khatab dapat dipercaya. Hal tersebut dapat dipercaya. Hal tersebut selanjutnya membuktikan bahwa sanad antara dia dengan Musa bin 'Aqabah bin Abi 'Aiyasyi adalah muttasil, (al-Asqallani: 438).

f. Abdullah Ibn Umar

Beliau adalah Abdullah bin Umar Khattab. Beliau dilahirkan tidak berselang lama setelah Muhammad diangkat menjadi rasul. Beliau tinggal dan meninggal di Madinah pada tahun $70 \mathrm{H}$ (As-Syirazi, 1952:19).

Orang-orang yang meriwayatkan Hadits kepada beliau adalah: Rasulullah saw., Umar bin. Khattab, Zaid (pamannya), Hafshah (saudarinya), Abu Bakar, Utsman bin. 'Affan, Ali bin. Abi Thalib, Sa'id, Abdullah bin. Mas'ud dan Aisyah.

Sedangkan murid-murid yang meriwayatkan Hadits dari beliau adalah (diantaranya): anak-anaknya sendiri, Bilal, Hamzah, Nafi', Ubaidullah. Beliau adalah seorang sahabat Rasulullah saw, yang tingkat ketsiqotannya paling tinggi, (Abdurrahman Hatim, t.t.:1989). Beberapa pernyataan kritikus tentang dirinya adalah sebagai berikut, (al-Asqallani: 368): 
1) Saudari perempuannya sekaligus istri Rasulullah saw. Pernah berkata bahwa ia pernah mendengar Rasul berkata bahwa beliau adalah orang yang shaleh, (Nawir Yuslem, 2001: 419).

2) Beliau adalah orang paling tsiqat menurut az-Zuhri.

3) Ibnu Zabir mengatakan bahwa beliau adalah orang yang paling tsabit.

Tidak diragukan lagi kebersambungan periwayatan beliau dengan Rasulullah saw., karena memang Rasulullah sendiri mengatakan bahwa beliau adalah orang yang shaleh.

\section{F. Kesimpulan}

1. Kritik sanad dan status Hadis Abdullah bin Umar

Berdasarkan pada uraian mengenai sanad Hadis Abdullah bin Umar tentang menjulurkan pakaian karena kesombongan di atas, yang di takhrijkan oleh Abu Daud, dapat di ambil beberapa catatan sebagai berikut:

a. Ditinjau dari segi kualitas pribadi dan kapasitas intelektual para perawinya, dapat disimpulkan bahwa seluruh para perawi Hadis yang meriwayatkan Hadis tersebut adalah tsiqat,

b. Dari segi hubungan perawiyatan, maka seluruhnya sanad Hadis tersebut adalah muttasil

Dari segi lambang-lambang periwayatan hadis, sebagian perawi mempergunakan hadtsana dan akhbarana yang menunjukkan dia memperoleh hadis tersebut secara langsung dan dengan metode alsama', namun sebagian lagi mempergunakan lambang 'an, sehingga karenanya Hadis tersebut dikatagorikan sebagai hadis mu'an'an. Hadis mu'an'an diperselihkan oleh para ulama hadis tentang kebersambungan sanadnya. Meskipun demikian, setelah dilakukan penelitian tentang kualitas pribadi para perawi nya dan hubungan masing-masing perawi dengan perawi yang sebelumnya, maka seluruh sanadnya dapat dibuktikan dalam keadaan bersambung.

Berdasarkan beberapa catatan di atas dapat disimpulkan bahwa sanad Hadis Abdullah bin Umar di atas telah memenuhi kriteria Hadis sahih, dan karenanya dapat dihukumkan sebagai Hadis Sahih.

\section{Kritik Matan Hadis yang diriwayatkan oleh Abu Daud}

Berdasarkan penelitian matan hadis tentan Isbal dalam berpakaian bahwa sebuah hadis secara matan dapat dikategorikan sahih manakala hadis tersebut telah dilakukan perbandingan dengan Alquran, hadis yang lain, dan sebagainya yang telah ditentukan tolok ukur keteria kesahihan matan hadis. Juga secara jelas dapat dibuktikan sejalan atau tidak bertentangan dengan ayat-ayat alquran atapun dengan hadishadis yang lain. 
a. Perbandingan dengan Alquran

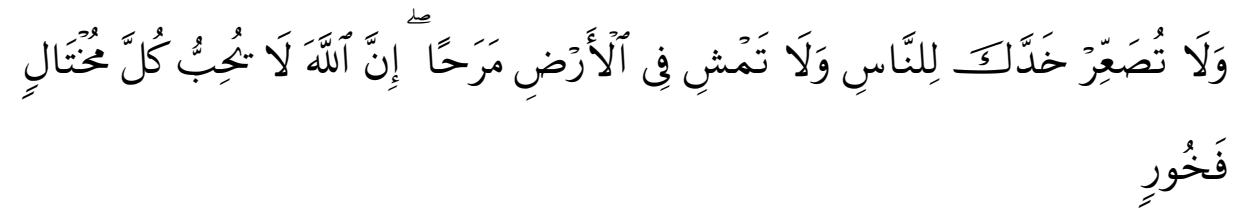

Artinya: Dan janganlah kamu memalingkan mukamu dari manusia (karena sombong) dan janganlah kamu berjalan di muka bumi dengan angkuh. Sesungguhnya Allah tidak menyukai orang-orang yang sombong lagi membanggakan diri. (Q.S. Lukman: 18)

b. Perbandingan dengan hadis, (al-Imam al-Bukhari, 1987:2182)

$$
\begin{aligned}
& \text { سمعت أبا هريرة يقول : قال النبي أو قال أبو القاسم صلى الله عليه و سلم (a) } \\
& \text { بينما رجل يمشي في حلة تعجبه نفسه مرجل جمته إذ خسف الله به فهو يتجلجل } \\
& \text { إلى يوم القيامة ) }
\end{aligned}
$$

Artinya: "Dari Abu Hurairah Rasulullah SAW bersabda: Seorang lelaki yang sedang berjalan dengan berpakaian sangat mewah yang membuat dirinya sendiri merasa kagum, dan rambutnya tersisir rapi. Tibatiba ia ditelan oleh longsoran tanah maka ia pun terus menerus berteriak ketakutan sampai hari kiamat. (HR. Al-Bukhari).

c. Perbandingan dengan logika

Dilihat dengan akal yang sehat hadis di atas tidak bertentanggan dengan logika karena berpakaian sangat di anjurkan dalam agama untuk menutupi aurat baik dalam shalat maupun di luar shalat dengan tidak menyombongkan diri.

d. Perbandingan dengan sejarah. Dari sejarah juga tidak bertentangan hadis di atas karena ummat sebelumnya juga di anjurkan berpakaian dengan semestinya

e. Perbandingan dengan tata bahasa. Dari segi tata bahasa diihat tidak ada bertentangan karena gaya bahasa yang digunaka sesuai dengan uslub baik segi kaidah sastra, balaghah dan lain-lain.

\section{BIBLIOGRAFI}

Al-Asqallani, Ibn Hajar. (1927). Tahżib at-Tahżib (Cet. I Juz. 1l). Beirut: Dar as-Sadir. Al-Bukhari. (n.d). Shahih Bukhori. Cairo: Daar al-Matabi' as-Sya'biyah.

Al-Ghumari. (1987). Al-Hidayah fi Takhrij Ahadist al-Bidayah. Riyadh: Alam al Kutub. Al-Ju'fi, Muhammad Ibn Ismail Abu 'Abdullah al-Bukhari. (1987). al-Jami'; asShahih al-Mukhtashar (Cet.3). Bairut: Dar-Ibn Kasir al-Yamamah.

Al-Khatib, Muhammad 'Ajjaj. (1989). Usul al-Hadis. Bairut: Dar al-Fikr.

An-Nasa'iy. (1978). Sunan an-Nasa’iy. Beirut: Daar al-Fikr.

An-Nasa'iy. (1968). Alfiyyatal-Hadist li al-Iraqi, juz III. Madinah: al-Maktabah asSalafiyah.

$\overline{\text { Al-Madãris, Volume 2 (1), } 2021}$ 
As-Sijistani, Abu Daud. (1952). Sunan Abi Daud. Mesir: Syarikah Maktabah wa Matba'ah al-Musthafa.

As-Syakhawi. (1968). Fathul Mughit: Syarh Alfiyyatal-Hadist li al-Iraqi (juz III). Madinah: al-Maktabah as-Salafiyah.

As-Syakhawi. (1987). Fathul Mughit: Syarh al-Gumari, al-Hidayah fi Takhrij Ahadist albidayah. Riyadh: Alam al Kutub.

As-Syirazi, Abu Ishaq. (n.d). Tabaqat al-Fuqaha'. Baghdad: Maktabah Nu'man alA'zhami.

Athar, Nuruddin. (1997). Manjah al-Naqd fil 'Ulum al-Hadis (cet. 2). Damaskus: Dar 1Fikr.

At-Tirmidzi. (n.d). Sunan at-Tirmidzi. Cairo: Maktabah wa Syrikah Muhammad Mahmud al-Halabi.

Hatim, Muhammad Abdurrahman. (n.d). Kitab Jarh wa at-Ta'dil. Beirut: Daar alKutub Ilmiyah.

Ibn Hanbal, Ahmad., \& al-Syaibani, Abu Abdullah. (n.d). Musnad Ahmad Ibn Hanbal, al-Qahirah: Muasiah Qirthabah.

Ibn Majah, Imam. (n.d). Sunan Ibnu Majah. Riyadh: Maktabah al-Ma'arif.

Ismail, Syuhudi. (1992). Metodologi Penelitian Hadist Nabi. Jakarta: Bulan Bintang.

Muslim, Imam. (1924). Shahih Muslim. Cairo: Maktabah al-Misriyah.

Wensinck, A.J., \& Abd. al-Baqi, Muhammad Fuad. (1936). Al-Mu'jam al-Mufahras li al-Alfadhi al-Hadits an-Nabawi. Leiden: Maktabah Bril.

Yuslem, Nawir. (2001). Ulumul Hadist. Jakarta: Mutiara Sumber Widiya.

$\overline{\text { Al-Madãris, Volume 2 (1), } 2021}$ 